Didaktik : Jurnal Pendidikan Guru Sekolah Dasar, ISSN : 24775673

Sekolah Tinggi Keguruan dan IImu Pendidikan Subang

Volume IV Nomor 2, Desember 2018

\title{
PENGGUNAAN MODEL DISCOVERY LEARNING UNTUK MENINGKATKAN HASIL BELAJAR SISWA KELAS IV PADA SUBTEMA KEBERSAMAAN DALAM KEBERAGAMAN
}

\author{
Dian Anjani ${ }^{1}$, Acep Roni Hamdani ${ }^{2}$ \\ 1,2Universitas Pasundan \\ 1diananjani96@gmail.com, 2acepronihamdani2@gmail.com
}

\begin{abstract}
Research this background by activities learn who is still centered to the teacher inside form method lecture so that student less active and results learn student still on under KKM. Research this aim for fix it and increase results learn student on subtheme togetherness in diversity through discovery learning models. Research this use method research action class at SDN Cikitu 03 grade IV with number of 30 students. Research action class this consists of of 3 cycles, each cycle there is two meeting with covering activities planning , implementation, observation or observation and reflection. Based on observation and reflection conducted on research this obtained results planning learning on the first cycle of $70 \%$. On cycle II planning learning increase to be $75 \%$, at cycle III obtains $86 \%$ yield. Implementation learning on cycle I got $72 \%$. On cycle II obtains results $80 \%$. On cycle III becomes by $90 \%$. $\mathrm{H}$ acyl an ti penili Act teacher's behavior with apply syntax discovery learning on cycle I obtained $66 \%$ result with category enough good. On cycle II obtains $76 \%$ with criteria good. On cycle III obtains results $86 \%$ with criteria very good. Response student to teacher's behavior on cycle I obtained percentage of 64 , $33 \%$ or categorized as enough good. Cycle II obtains 74, 33 \% or categorized as response student good. On cycle III obtains $86.61 \%$ or said response student very good. Results learn on the cycle I reaches KKM value by $37 \%$ to criteria enough, cycle II reaches KKM as much as $57 \%$ with criteria well , cycle III reaches KKM value as much as $90 \%$ with criteria very good. this showing that use of discovery learning models could increase results learn student on subtheme togetherness in diversity in class IV SDN Cikitu 03. With Thus, the use of discovery learning models could made wrong one learning model for applied on theme beautiful togetherness subtheme togetherness in diversity .
\end{abstract}

Keywords: Discovery Learning, learning outcomes

\section{ABSTRAK}

Penelitian ini dilatarbelakangi oleh kegiatan belajar yang masih berpusat pada guru dalam bentuk metode ceramah sehingga siswa kurang aktif dan hasil belajar siswa masih di bawah KKM. Penelitian ini bertujuan untuk memperbaiki dan meningkatkan hasil belajar siswa pada subtema kebersamaan dalam keberagaman melalui model discovery learning. Penelitian ini menggunakan metode penelitian tindakan kelas di SDN Cikitu 03 kelas IV dengan jumlah 30 siswa. Penelitian tindakan kelas ini terdiri dari 3 siklus, setiap siklus terdapat dua pertemuan dengan meliputi kegiatan perencanaan, pelaksanaan, 
observasi atau pengamatan dan refleksi. Berdasarkan pengamatan dan refleksi yang dilaksanakan pada penelitian ini diperoleh hasil perencanaan pembelajaran pada siklus I sebesar $70 \%$. Pada siklus II perencanaan pembelajaran meningkat menjadi $75 \%$, pada siklus III memperoleh hasil $86 \%$. Pelaksanaan pembelajaran pada siklus I memperoleh $72 \%$. Pada siklus II memperoleh hasil $80 \%$. Pada siklus III menjadi sebesar $90 \%$. Hasil penilitian tingkah laku guru dengan menerapkan sintak discovery learning pada siklus I memperoleh hasil $66 \%$ dengan kategori cukup baik. Pada siklus II memperoleh $76 \%$ dengan kriteria baik. Pada siklus III memperoleh hasil $86 \%$ dengan kriteria sangat baik. Respon siswa terhadap tingkahlaku guru pada siklus I memperoleh persentase $64,33 \%$ atau dikategorikan cukup baik. Siklus II memperoleh $74,33 \%$ atau dikategorikan respon siswa baik. Pada siklus III memperoleh $86,61 \%$ atau dikatakan respon siswa sangat baik. Hasil belajar pada siklus I yang mencapai nilai KKM sebanyak 37\% dengan kriteria cukup, siklus II yang mencapai nilai KKM sebanyak 57\% dengan kriteria baik, siklus III yang mencapai nilai KKM sebanyak $90 \%$ dengan kriteria sangat baik. Hal ini menunjukan bahwa penggunaan model discovery learning dapat meningkatkan hasil belajar siswa pada subtema kebersamaan dalam keberagaman di kelas IV SDN Cikitu 03. Dengan demikian, penggunaan model discovery learning dapat dijadikan salah satu model pembelajaran untuk diterapkan pada tema indahnya kebersamaan subtema kebersamaan dalam keberagaman.

Kata Kunci: Discovery Learning, Hasil Belajar

\section{A. Pendahuluan}

Pendidikan merupakan salah satu hal yang terpenting dalam kehidupan manusia, karena melalui pendidikan akan dapat menciptakan manusia yang berpotensi, kreatif dan memiliki ide cemerlang sebagai bekal untuk memperoleh masa depan yang baik. Hal tersebut sesuai dengan amanat UU nomor 20 Tahun 2003 Pasal 1 ayat 1 Tentang Sistem Pendidikan Nasional, dalam (Sanjaya 2006, hlm.2) yaitu:

Pendidikan adalah usaha sadar dan terencana untuk mewujudkan suasana belajar dan proses pembelajaran agar siswa secara aktif mengembangkan potensi dirinya untuk memiliki kekuatan spiritual keagamaan, pengendalian diri, kepribadian, kecerdasan, akhlak mulia, serta keterampilan yang diperlukan dirinya, bangsa dan negara.

Berdasarkan undang-undang tersebut maka pendidikan pada dasarnya merupakan suatu interaksi dua arah antara guru dengan siswa dalam kegiatan belajar dan mengajar untuk mencapai suatu tujuan pendidikan, yang berlangsung dalam proses pembelajaran. Mengenai hal ini guru berperan sebagai pelaksanaan pendidikan dilapangan diharapkan dapat berperan sebagai fasilitator yang 
akan memfasilitasi siswa dalam belajar, dan siswa sendirilah yang harus aktif belajar dari berbagai sumber belajar.

Berhasilnya tujuan pembelajaran ditentukan oleh banyak faktor diantaranya adalah faktor guru dalam melaksanakan proses pembelajaran, karena guru merupakan orang yang berhadapan langsung dengan siswa dan guru secara langsung dapat mempengaruhi, membina dan meningkatkan kecerdasan serta keterampilan siswa. Menurut Hamalik (2011, hlm.76) menyatakan "Yang menjadi kunci dalam rangka menentukan tujuan pembeajaran adalah kebutuhan siswa, mata pelajaran, dan guru itu sendiri".

Untuk dapat melaksanakan tugasnya secara profesional, seorang guru dituntut untuk dapat memahami dan memiliki keterampilan yang memadai dalam mengembangkan berbagai model pembelajaran yang efektif, kreatif dan menyenangkan, guru juga harus bisa memilih model pembelajaran yang tepat dan sesuai dengan konsep-konsep mata pelajaran yang akan disampaikan. Untuk itu diperlukan suatu upaya dalam rangka meningkatkan mutu pendidikan dan pengajaran salah satunya adalah dengan memilih model atau cara dalam menyampaikan materi pelajaran agar diperoleh peningkatan hasil belajar siswa.
Trianto (2010, hlm. 51) menyatakan:

Model pembelajaran adalah suatu perencanaan atau suatu pola yang digunakan sebagai pedoman dalam merencanakan pembelajaran dikelas atau pembelajaran dalam tutorial. Fungsi model pembelajaran adalah sebagai pedoman bagi perancang pengajar dan para guru dalam melaksanakan pembelajaran.

Berdasarkan uraian tersebut menyatakan bahwa model pembelajaran yaitu suatu pola yang digunakan guru untuk membantu siswa dalam mengorganisasikan pengalaman belajar untuk mencapai tujuan belajar dan berfungsi sebagai pedoman bagi guru dalam melaksanakan pembelajaran. Sehubungan dengan hal tersebut maka guru perlu memahami secara benar dalam menguasai model pembelajaran yang sesuai dengan materi dan tujuan pembelajaran untuk meningkatkan hasil belajar siswa.

Kemampuan guru sangat dibutuhkan dalam menguasai model pembelajaran yang diterapkan dalam pengajaran di dalam kelas karena model pembelajaran menjadi sangat penting dalam mendukung keberhasilan pembelajaran yang dapat dilihat dari tercapainya tujuan pembelajaran, karna tujuan dari 
model pembelajaran agar proses pembelajaran semakin bervariasi, tidak membosankan, lebih efektif dan memebuat siswa menjadi lebih aktif, berfikir kritis dan bersemangat karna mereka terlibat langsung dalam proses pembelajaran.

Keberhasilan pembelajaran siswa dapat dilihat dari hasil belajar siswa. Hasil belajar adalah hasil yang diperoleh oleh siswa setelah melakukan pembelajaran yang diajukan dengan nilai tes yang dilakukan oleh guru, karena hasil belajar merupakan indikator yang paling mudah untuk menentukan tingkat keberhasilan siswa dalam berbagai mata pelajaran. Sejalan dengan pendapat yang diungkapkan Sudjana (2013, hlm. 3) "Hasil belajar siswa pada hakikatnya adalah perubahan tingkah laku sebagai hasil belajar dalam pengertian yang lebih luas mencakup bidang kognitif, afektif, dan psikomotorik". Selanjutnya Syaodih (2011, hlm.102) mengatakan "Penguasaan hasil belajar oleh seseorang dapat dilihat dari perilakunya, baik perilaku dalam bentuk penguasaan pengetahuan, keterampilan berpikir maupun keterampilan motorik".

Berdasarkan uraian diatas maka dapat dinyatakan bahwa hasil belajar merupakan tingkat penguasaan pelajaran sesuai dengan tujuan yang diharapkan yang sesuai dengan bidang kognitif, afektif dan psikomotor.
Berdasarkan hasil observasi yang dilakukan peneliti pada siswa kelas IV SD Negeri Cikitu 03 Kec.Pacet Kab.Bandung terdapat masalah dimana saat pembelajaran siswa kurang aktif sehingga hasil belajar siswa masih rendah, salah satunya terjadi karena belum sesuainya penerapan model pembelajaran dalam proses penyampaian materi guru masih mengajar menggunakan metode ceramah dan belum menggunakan moedel pembelajaran discovery learning. Semua itu terkendala pada metode pengajaran yang digunakan guru, maka kondisi tersebut tidak akan meningkatkan hasil belajar siswa secara optimal. Masalah yang dihadapi dalam proses pembelajaran adalah guru yang berperan sangat dominan dan pembelajaran hanya berpusat pada guru jadi pada kegiatan pembelajaran guru menjadi satu satunya sumber ilmu ( teacher center) sehingga siswa kurang aktif karena tidak diberikan kesempatan untuk terlibat dalam kegiatan pembelajaran. Hal itu terjadi karena kurang optimalnya cara penyampaian materi pembelajaran yang dilakukan guru cenderung membosankan dan monoton sehingga menyebabkan siswa kurang memahami materi yang dijelaskan. Sementara itu guru juga masih kesulitan dalam menggunakan model pembelajaran yang tepat dan sesuai dengan 
kondisi siswa selama proses pembelajaran berlangsung akhirnya masih banyak siswa yang kurang memahami materi pembelajaran yang disampaikan guru sehingga hasil belajar siswa masih rendah.

Berdasarkan hasil survey yang dilakukam pada SDN Cikitu

Tabel 1. Data Nilai KKM Siswa Kelas IV SDN Cikitu 03

\begin{tabular}{|c|c|c|c|c|}
\hline No. & KKM & Keterangan & Siswa & Presentase (\%) \\
\hline 1. & 70 & Tuntas & 10 & 33,33 \\
\hline 2. & 70 & Belum tuntas & 20 & 66,66 \\
\hline \multicolumn{3}{|c|}{ Jumlah } & 30 & $100 \%$ \\
\hline
\end{tabular}

Sumber: Arsip nilai wali kelas IV SDN Cikitu 03

Berdasarkan tabel diatas

menunjukan bahwa siswa yang memperoleh nilai diatas Kriteria Ketuntasan Minimal (KKM) hanya 10 siswa dari 30 siswa atau sekitar $33,33 \%$. Sedangkan sekitar $66,66 \% 20$ siswa dari 30 siswa belum mencapai KKM. Dengan demikian tingkat pemahaman siswa terhadap materi masih jauh dari yang diharapkan, dilihat dari jumlah presentase nilai belum tuntas siswa lebih besar dari pada tingkat ketuntasan siswa, jadi dapat disimpulkan bahwa nilai hasil belajar siswa kelas IV SDN Cikitu 03 relatif rendah.

Nilai hasil belajar dapat dipakai sebagai nilai ahir keberhasilan dalam proses pembelajaran di sekolah dan juga mengukur kinerja guru dalam melaksanakan proses pembelajaran. Oleh karna itu perlu
03 diperoleh data nilai hasil belajar yang dicapai siswa kelas IV umumnya kurang optimal. Data yang diperoleh pada nilai KKM hasil ajaran 2017/2018 seperti tabel berikut ini: ujian tengah semester ganjil tahun digunakan sebuah model pembelajaran yang dapat menempatkan siswa sebagai subjek (pelaku) pembelajaran dan guru hanya bertindak sebagai fasilitator dalam proses pembelajaran tersebut. Dengan demikian proses pembelajaran harus disajikan melalui hal-hal yang bersifat penemuan sesuai dengan tingkatan kemampuan siswa pada jenjang pendidikannya.

Model pembelajaran sangat penting diterapkan dalam proses pembelajaran, karena pada dasarnya keterbatasan peserta didik melalui model pembelajaran yang sesuai dengan materi yang akan diajarkan salah satunya dengan menerapkan model pembelajaran discovery learning (DL). Menurut Sadirman (2012, hlm.145) "Dalam mengaplikasikan model pembelajaran Discovery 
Learning guru berperan sebagai pembimbing dengan memberikan kesempatan kepada siswa untuk belajar secara aktif, sebagaimana pendapat guru harus dapat membimbing dan mengarahkan kegiatan belajar siswa sesuai dengan tujuan". Bruner dalam Slameto (2013, hlm.11) mengungkapkan "discovery learning ialah lingkungan di mana siswa dapat melakukan eksplorasi, penemuan-penemuan baru yang belum dikenal".

Berdasarkan pendapat di atas, dapat dinyatakan bahwa model discovery learning merupakan salah satu model pembelajaran dimana seorang guru tidak perlu berdiri menjelaskan materi secara meneyeluruh didepan kelas, yang diperlukan oleh para siswa adalah situasi atau lingkungan yang mendukung siswa untuk belajar dan guru memberikan kebebasan untuk mencari dan menemukan sendiri dimana siswa dapat melakukan eksplorasi, penemuan-penemuan baru yang belum diketahui.

Dengan demikian untuk meningkatkan hasil belajar siswa guru harus bisa menggunakan model pembelajaran yang lebih menarik agar dapat melibatkan siswa secara aktif dalam proses pembelajaran salah satunya dengan menggunakan model discovery learning yang bertujuan agar siswa belajar aktif mencari dan menemukan materi pembelajaran sebagai dasar pemahaman sebenarnya dalam belajar yang terjadi melalui penemuan sendiri sehingga siswa bisa memahami materi pembelajaran dan meningkatkan hasil belajar siswa.

Berdasarkan latar belakang masalah tersebut, maka sesuai dengan hasil pengamatan, penulis berusaha untuk memperbaiki pembelajaran dengan menggunakan model discovery learning melalui penelitian tindakan kelas. Karena penelitian tindakan kelas merupakan cara yang tepat untuk mengatasi masalah tersebaut agar hasil belajar siswa sesuai yang diharapkan. Dengan demikian penulis mengambil kesimpulan untuk melakukan penelitian yang berjudul "Penggunaan Model Discovery Learning Untuk Meningkatkan Hasil Belajar Siswa Kelas IV pada Subtema Kebersamaan Dalam Keberagaman". ( Penelitian Tindakan Kelas Tema Indahnya Kebersamaan Pada Siswa Kelas IV SDN Cikitu 03. JIn. Cikitu Desa Cikitu Kecamatan Pacet Kabupaten Bandung).

\section{B. Landasan Teori}

\section{Model Discovery Learning}

a. Pengertian Model Discovery Learning

Menurut Hosnan (2014, hlm. 282) menyatakan "Pembelajaran discovery learning adalah suatu 
model untuk mengembangkan cara belajar siswa aktif dengan menemukan sendiri, menyelidiki sendiri, maka hasil yang diperoleh akan setia dan tahan lama dalam ingatan, tidak akan mudah dilupakan siswa. Menurut Suherman (2015, hlm.15) dalam Jurnal Biologi Edukasi Edisi 14 N0;1, Vol VII, Edisi Juni 2015 mengatakan "Model pembelajaran discovery learning adalah model mengajar yang mengatur pengajaran sedemikian rupa sehingga anak memperoleh pengetahuan yang sebelumnya belum diketahuinya itu tidak melalui pemberitahuan, sebagian atau seluruhnya ditemukan sendiri". Menurut Buldiningsih (2005, hlm. 107) "Model discovery learning adalah memahami konsep, arti, dan hubungan, melalui proses intuitif untuk akhirnya sampai kepada suatu kesimpulan".

Pada pembelajaran discovery bahwa kegiatan atau pembelajaran dirancang sedemikian rupa sehingga siswa dapat menemukan konsep-konsep dan prinsip-prinsip melalui proses penemuannya sendiri. Bruner dalam (Dahar, 1996, hlm. 103) menyatakan "Belajar penemuan (discovery learning) sesuai pencarian dengan pencarian pengetahuan secara aktif oleh manusia, dan dengan sendirinya memberikan hasil yang paling baik. Berusaha sendiri untuk mencari pemecahan masalah serta pengetahuan yang menyertainya, menghasilkan pengetahuan yang benar-benar bermakna". Suryosubroto (2009, hlm. 178) menyatakan:

Metode penemuan (discovery) diartikan sebagai prosedur mengajar yang mementingkan pengajaran, perseorangan, manipulasi obyek dan percobaan, sebelum sampai kepada generalisasi. Sehingga metode penemuan (discovery) merupakan komponen dari praktik pendidikan yang meliputi metode mengajar yang memajukan cara belajar aktif, berorientasi pada proses, MK mengarahkan sendiri, mencari sendiri, dan reflektif.

Sardiman (2012, hlm. 145) "Dalam mengaplikasikan model pembelajaran Discovery Learning guru berperan sebagai pembimbing dengan memberikan kesempatan kepada siswa untuk belajar secara aktif, sebagaimana pendapat guru harus dapat membimbing dan mengarahkan kegiatan belajar siswa sesuai dengan tujuan". Woolfolk dalam (Trianto, 2012, hlm. 80) "Dalam pembelajaran melalui penemuan, guru memberikan contoh dan siswa bekerja berdasarkan contoh tersebut sampai menemukan hubungan antar bagian dari suatu struktur materi”. Menurut Putrayasa dalam Jurnal Pena IImiah: Vol. 1, No. 1 Edisi 2016 menyatakan "Melalui model discovery learning siswa menjadi lebih dekat dengan apa 
yang menjadi sumber belajarnya, rasa percaya diri siswa akan meningkat karena dia merasa apa yang telah dipahaminya ditemukan oleh dirinya sendiri, kerjasama dengan temannya pun akan meningkat, serta tentunya menambah pengalaman siswa".

Depdikbud dalam Indahsari (2014, hlm. 14) menyebutkan "Discovery Learning mempunyai prinsip yang hampir sama dengan inquiri, namun terdapat perbedaan antara keduanya yaitu mengenai belajara discovery ada juga yang menyebutnya sebagai belajar inkuiri atau inquiry learning, tetapi pada dasarnya merupakan suatu kegiatan belajar yang mengutamakan aktivitas anak". Menurut Aini (2016, hlm. 11) menyatakan "Pada Discovery masalah yang diperhadapkan kepada siswa semacam masalah yang direkayasa oleh guru, sedangkan pada inkuiri masalahnya bukan hasil rekayasa, sehingga siswa harus mengerahkan seluruh pikiran dan keterampilannya untuk mendapatkan temuan-temuan di dalam masalah itu melalui proses penelitian". Sukmadinata (2011, hlm. 183) "Pada Inquiri menekankan kepada proses mencarinya, sedangkan discovery kepada menemukannya. Jika sesorang melakukan pencarian (inquiri) kemungkinan besar akan menemukan, dan suatu penemuan (discovery) adalah hasil dari suatu pencarian". Oleh karena itu dapat dikatakan bahwa discovery dan inquiry merupakan suatu rangkaian kegiatan pembelajaran yang melibatkan secara maksimal seluruh kemampuan peserta didik untuk mencari dan menyelidiki secara sistematis, kritis dan logis sehingga mereka dapat menemukan sendiri pengetahuan, sikap dan keterampilan sebagai wujud adanya perubahan perilaku.

Berdasarkan pendapat di atas dapat dinyatakan bahwa model discovery learning adalah suatu belajar penemuan untuk mengembangkan cara belajar siswa aktif dengan cara melakukan suatu pengamatan dan penelitian dari masalah yang diberikan oleh guru pada kegiatan pembelajaran yang bertujuanagar siswa berperan sebagai subjek belajar dan mendorong siswa memiliki kemampuan untuk mencari dan menemukan sendiri pengetahuannya karena pada umumnya pengetahuan diperoleh dari pengalamannya hasil dari penemuannya sendiri dalam pembelajaran di kelas.

\section{b. Tujuan Model Discovery Learning \\ Setiap model pembelajaran} mempunyai tujuan yang ingin dicapai. Bell dalam Hosnan (2014, hlm. 284) mengemukakan beberapa tujuan spesifik dari pembelajaran dengan discovery learning diantaranya: 
1) Dalam penemuan siswa memiliki kesempatan untuk terlibat secara aktif dalam pembelajaran. Kenyataan menunjukan bahwa partisipasi siswa dalam pembelajaran meningkat ketika penemuan digunakan.

2) Melalui pembelajaran dengan penemuan, siswa belajar menemukan pola dalam situasi konkrit maupun abstrak, juga siswa banyak meramalkan (extrapolate) informasi tambahan yang diberikan.

3) Siswa juga belajar merumuskan strategi tanya jawab yang tidak ranvu dan menggunakan tanya jawab untuk memperoleh informasi yang bermanfaat dalam menemukan.

4) Pembelajaran dengan penemuan memebantu siswa memebentuk cara kerja bersama yang efektif sehingga memebagi informasi, serta mendengar dan menggunakan ide-ide orang lain.

5) Terdapat beberapa fakta yang menunjukan bahwa keterampilan-keterampilan konsep-konsep dan prinsipprinsip yang dipelajari melalui penemuan lebih bermakna.

6) Keterampilan yang dipelajari dalam situasi belajar penemuan dalam beberapa kasus, lebih mudaah ditransfer untuk aktivitas baru dan diaaplikasikan dalam situasi belajar yang baru.
Tujuan model pembelajaran discovery learning menurut Azhar dalam Aini (2016 hlm. 99) adalah:

1) Kemampuan berfikir agar lebih tanggap, cermat dan melatih daya nalar (kritis, analisis dan logis)

2) Membina dan mengembangkan sikap ingin lebih tahu

3) Mengembangkan aspek kognitif, afektif dan psikomotorik.

4) Mengembangkan sikap, keterampilan kepercayaan murid dalam memutuskan sesuatu secara tepat dan objektif.

Berdasarkan pendapat diatas dapat dinyatakan bahwa tujuan disovery learning yaitu suatu model pembelajaran yang bertujuan menciptakan siswa terlibat secara aktif dan mandiri dalam menemukan solusi dari masalah pada kegiatan pembelajaran, serta melatih kemampuan berfikir kritis, mengembangkan sikap ingin lebih tau dan keterampilan percaya diri dalam memutuskan sesuatu secara objektif.

\section{c. Karakteristik Model Discovery Learning}

Hosnan (2014, hlm. 284), ciri belajar menemukan, yaitu (1) mengeksplorasi dan memecahkan masalah untuk menciptakan, menggabungkan, dan menggeneralisasi pengetahuan; (2) berpusat pada siswa; (3) kegiatan untuk menggabungkan pengetahuan baru dan pengetahuan yang sudah ada. Ada sejumlah ciri-ciri proses 
pembelajaran yang sangat ditekankan oleh teori kontruktivisme, yaitu sebagai berikut:

1) Menemukan pada proses belajar bukan proses mengajar.

2) Mendorong terjadinya kemandirian dan inisiatif belajar pada siswa.

3) Memandang siswa sebagai pencipta kemauan dan tujuan yang ingin dicapai.

4) Berpandang bahwa belajar merupakan suatu proses, bukan menekan pada hasil.

5) Mendorong siswa untuk mampu melekukan penyelidikan.

6) Menghargai peranan pengalaman kritis dalam belajar.

7) Mendorong berkembangnya rasa ingin tahu secara alami pada siswa.

8) Penilaian belajar lebih menekankan pada kinerja dan pemahaman siswa.

9) Mendasarkan proses belajarnya pada prinsip-prinsip kognitif.

10) Banyak menggunakan terminlogi kognitif untuk menjelaskan proses pembelajaran seperti prediksi, inferensi, kreasi dan analisis.

11) Menekankan "bagaimana" siswa belajar.

12) Mendorong siswa untuk berpartisipasi aktif dalam dialog atau diskusi dengan siswa lain dan guru.

13) Sangat mendukung terjadinya belajar kooperatif.
14) Menekankan pentingnya konteks dalam belajar.

15) Memperhatikan keyakinan dan sikap siswa dalam belajar.

16) Memberikan kesempatan kepada siswa untuk membangun pengetahuan dan pemahaman baru yang didasari pada pengalaman nyata.

Berdasarkan ciri-ciri pembelajaran konstruktivisme tersebut, Peneliti menyatakan bahwa karakteristik discovery learning yaitu sebagai berikut.

1) Pembelajaran yang menuntut siswa aktif bertanya,mencari dan berinteraksi dengan teman yang lainnya sehingga hubungan baik akan terjalin.

2) Menjadikan siswa agar bisa belajar mandiri dan mampu menyelidiki serta mencari penemuan-penemuan baru dari informasi yang mereka temukan.

3) Memupuk rasa tanggung jawab dalam diri siswa dalam menyelesaikan tugas-tugas dan masalah yang dihadapinya dalam pembelajaran di kelas.

Langkah-langkah model discovery learning diterapkan dengan 6 langkah yaitu sebagai berikut (Ramdani dan Widyastuti):

1) Stimulasi, guru memotivasi dan mengajak siswa untuk menjawab pertanyaan yang diberikan guru sesuai dengan materi yang akan dipelajari.

2) Problem statement (pertanyaan/identifikasi 
masalah), guru memaparkan hipotesis tentang hal-hal yang harus diperhatikan pada materi pembelajaran. Siswa diberikan kesempatan untuk berdiskusi dengan siswa lainnya dengan cara dibuat kelompok kecil, kemudian diminta untuk mengidentifikasi masalah terlebih dahulu agar nantinya semua siswa dapat menyelesaikan masalah tersebut.

3) Collecting information, siswa mengamati buku siswa serta teks bacaan dan mengaitkannya dengan data/informasi dari berbagai sumber tentang hal-hal yang harus diperhatikan dalam materi pembelajaran.

4) Data processing. Setelah mengumpulkan informasi, siswa memprosesnya dengan teman sekelompok.

5) Data verification. Setelah memproses data, para siswa melakukan verifikasi ke kelompok lain apakah sesuai dengan pemikiran mereka tentang hal-hal yang harus diperhatikan dalam materi pembelajaran.

6) Generalization. Siswa menggeneralisasi/membuat kesimpulan dan hasilnya dipaparkan di depan kelas.

\section{Hasil Belajar}

\section{a. Pengertian Hasil Belajar}

Hamalik (2008, hlm. 155) menyatakan "Hasil belajar adalah sebagai terjadinya perubahan tingkah laku pada diri seseorang yang dapat diamati dan diukur dalam bentuk pengetahuan, sikap dan keterampilan. Perubahan tersebut dapat di artikan sebagai terjadinya peningkatan dan pengembangan yang lebih baik sebelumnya yang tidak tahu menjadi tahu". Menurut Sudjana (2013, hlm. 22) "Hasil belajar adalah kemampuan-kemampuan yang dimiliki siswa setelah ia menerima pengalaman belajarnya". Purwanto (2013, hlm. 34) "Hasil belajar merupakan perubahan siswa akibat belajar. Perubahan itu diupayakan dalam proses belajar mengajar untuk mencapai tujuan pendidikan". Hamalik (2009, hlm. 59) menyatakan "Hasil belajar menunjukkan kepada prestasi belajar, sedangkan prestasi belajar merupakan indikator adanya derajat perubahan tingkah laku siswa".

Berdasarkan pendapat di atas dapat dinyatakan bahwa hasil belajar merupakan suatu penilaian ahir dari proses perubahan yang terjadi pada siswa dalam bentuk pengetahuan, sikap, dan keterampilan setelah mengikuti proses belajar mengajar, perubahan yang terjadi yaitu perubahan tingkah laku maupun perubahan pengetahuannya baik dari hasil belajar ataupun hasil pengalamannya.

b. Tujuan Penilaian Hasil Belajar 
Hamalik (2011, hlm. 160) Evaluasi hasil belajar memiliki tujuan-tujuan tertentu yaitu:

1) Memberikan informasi tentang kemajuan siswa dalam upaya mencapai tujuan-tujuan belajar melalui berbagai kegiatan belajar.

2) Memberikan informasi yang dapat digunakan untuk membina kegiatan-kegiatan belajar siswa lebih lanjut, baik keseluruhan kelas maupun masing-masing individu.

3) Memberikan informasi yang dapat digunakan untuk mengetahui kemampuan siswa, menetapkan kesulitankesulitannya dan menyerahkan kegiatan kegiatan remedial (perbaikan)

4) Memberikan informasi yang dapat digunakan sebagai dasar untuk mendorong motivasi belajar siswa dengan cara mengenal kemajuan sendiri dan merangsangnya untuk melakukan upaya perbaikan.

Sudjana (2013, hlm. 4) mengatakan tujuan penilaian hasil belajar yaitu:

1) Mendeskripsikan kecakapan belajar para siswa sehingga dapat dikerahui kelebihan dan kekurangannya dalam berbagai bidang studi atau mata pelajaran yang ditempuhnya.

2) Mengetahui keberhasilan proses pendidikan dan pengajaran di sekolah, yakni sebarapa jauh keefektifannya dalam mengubah tingkah laku para siswa ke arah tujuan pendidikan yang diharapkan

3) Menentukan tindkat lanjut hasil penilaian, yakni melakukan perbaikan dan penyempurnaan dalam hal program pendidikan dan pengajaran serta strategi pelaksanaannya. Kegagalan para siswa dalam hasil belajar yang dicapainya hendaknya tidak dipandang sebagai kekurangan pada diri siswa semata-mata, tetapi juga bisa disebabkan oleh program pengajaran yang diberikan kepadanya atau oleh kesalahan strategi dalam melaksanakan program tersebut.

4) Memberikan

pertanggungjawaban

(accountability) dari pihak sekolah kepada pihak-pihak yang berkepentingan. Pihak yang dimaksud meliputi pemerintah, masyarakat, dan para orangtua siswa. Dalam mempertanggungjawabkan hasil-hasil yang telah dicapainya, sekolah memberikan laporan sebagai kekuatan dan kelemahan pelaksanaan system pendidikan dan pengajaran serta kendala yang dihadapinya.

Berdasarkan pendapat diatas dapat dinyatakan bahwa tujuan penilaian hasil belajar yaitu memberikan informasi hasil belajar siswa pada kegiatan belajar sehingga dapat diketahui 
kekurangan dan kelebihan serta kesulitan-kesulitan yang dihadapi siswa dalam proses pembelajaran tersebut, tetapi pada dasarnya tujuan tersebut tidak hanya mengevaluasi siswa, tetapi seluruh komponen dalam proses pembelajaran sehingga dengan tujuan tersebut dapat mengetahui keberhasilan proses pembelajaran yang bisa dilihat dari berhasil atau tidaknya guru dalam melaksanakan proses belajar mengajar. Apabila hasilnya kurang baik maka dapat dilakukan perbaiakan sehingga dapat memberikan pertanggungjawaban terhadap pihak sekolah.

\section{c. Pendekatan Penilaian Hasil} Belajar

Arifin (2012, hlm. 75) menyatakan "Pendekatan merupakan sudut pandang seseorang dalam mempelajari sesuatu. Dengan demikian, pendekatan evaluasi merupakan sudut pandang seseorang dalam menelaah atau mempelajari evaluasi". Ratnawulan (2014, HIm. 258) menyatakan "Pendekatan merupakan suatu cara atau sudut pandang sesorang dalam mempelajari sesuatu".

Terdapat dua pendekatan yang dapat digunakan untuk mengolah nilia nilai menjadi nilai ahir seoang siswa yang dapat dilakukan dengan mengacu kepada dua kriteria atau patokan, yaitu penilaian acuan patokan (criterionreferenced evaluation) dan penilaian acuan norma (normreferenced evaluation).

1) Penilaian Acuan Patokan (PAP)

Menurut Slameto dalam Arfan (2015, hlm. 161) menyatakan "Penilaian acuan patokan (PAP) atau dikenal dengan istilah Criterion Referenced Test adalah penilaian yang mengacu kepada kriteria pencapaian tujuan pembelajaran yang telah dirumuskan sebelumnya. Nilai-nilai yang diperoleh peserta didik dikaitkan dengan tingkat pencapaian penguasaan (mastery) peserta didik tentang materi pengajaran sesuai dengan tujuan pembelajaran yang telah ditetapkan". Purwanto (2009. HIm. 76) menyatakan "Suatu penilian disebut PAP jika dalam melakukan penilaian itu kita mengacu kepada suatu kriteria pencaopaian tujuan (instruksional) yang telah dirumuskan sebelumnya". Menurut Nurbayani dalam artikel penilaian acuan patokan (PAP) di perguruan tinggi (prinsip dan operasionalnya) mengatakan "PAP meneliti apa yang dapat dikerjakan oleh peserta didik dan bukan membandingkan seorang peserta didik dengan teman sekelasnya, melainkan dengan suatu kriteria atau patokan yang spesifik. Kriteria yang dimaksud adalah suatu tingkat pengalaman belajar atau sejumlah kompeten si dasar yang telah ditetapkan terlebih dahulu sebelum kegiatan belajar berlangsung". 
Arifin (2012, hlm. 77) menyatakan Penilaian Acuan Patokan yaitu:

"Pendekatan ini sering juga disebut penilaian norma absolut. Jika Anda ingin menggunakan pendekatan ini, berarti Anda harus membandingkan hasil yang diperoleh peserta didik dengan sebuah patokan atau kriteria yang secara absolut atau mutlak telah ditetapkan oleh guru. Anda juga dapat menggunakan langkah-langkah tertentu untuk menggunakan PAP, seperti menentukan skor ideal, mencari rata-rata dan simpangan baku ideal, kemudian menggunakan pedoman konversi skala nilai. Pendekatan ini cocok digunakan dalam evaluasi atau penilaian formatif yang berfungsi untuk perbaikan proses pembelajaran".

Arifin dalam Arfan (2015, hlm. 163) menyatakan "Tujuan PAP adalah untuk mengukur secara pasti tujuan atau kompetensi yang ditetapkan sebagai kriteria keberhasilannya. Penilaian acuan patokan bermanfaat dalam upaya meningkatkan kualitas hasil belajar, sebab peserta didik diusahakan untuk mencapai standar yang telah ditentukan dan hasil belajar peserta didik dapat diketahui derajat pencapainya".

Arifin (2012, hlm. 163) menyatakan "Untuk menentukan batas lulus (passing grade) dengan pendekatan PAP maka setiap skor peserta didik dibandingkan dengan skor ideal yang mungkin dicapai oleh peserta didik. Misalnya dalam suatu tes ditetapkan skor idealnya adalah 100, maka peserta didik yang memperoleh skor 65 sama dengan memperoleh nilai 6,5 dalam skala 0 - 10. Demikian seterusnya". Berdasarkan pengertian di atas, dapat dinyatakan bahwa dalam menggunakan PAP, seorang guru harus sudah dapat menyusun pedoman konversi skor menjadi skor standar sebelum kegiatan evaluasi dimulai. Oleh sebab itu, hasil pengukuran dari waktu ke waktu acuan penilaian kelompok yang sama atau berbeda dapat dipertahankan keajegannya. PAP dapat menggambarkan prestasi belajar peserta didik secara objektif apabila alat ukur yang digunakan adalah alat ukur yang standar.

2) Penilaian Acuan Norma (PAN)

Arfan (2015, hlm. 169) menyatakan "Penilaian acuan norma (PAN) atau dikenal dengan istilah Norm Referenced Test adalah penilaian yang dilakukan dengan mengacu pada norma kelompok. Nilai-nilai yang diperoleh peserta didik diperbandingkan dengan nilai-nilai peserta didik lainnya yang termasuk di dalam kelompoknya”. Ratnawulan (2014, HIm. 266) menyatakan Penilaian Acuan Norma, yaitu: Acuan norma merupakan elemen pilihan yang memeberikan daftar dokumen normatif yang diacu dalam standar sehingga acuan tersebut tidak 
terpisahkan dalam penerapan standar. Artinya pemberian nilai mengacu pada perolehan nilai di kelompok itu. Arifin (2012, hlm. 77) menyatakan penilaian acuan norma (PAN) yaitu:

"Salah satu perbedaan PAP dengan PAN adalah penggunaan tolak ukur hasil/skor sebagai pembanding. Pendekatan ini membandingkan skor setiap peserta didik dengan teman satu kelasnya. Makna nilai dalam bentuk angka maupun kualifikasi memiliki sifat relatif. Artinya, jika Anda sudah menyusun pedoman konversi skor untuk suatu kelompok, maka pedoman itu hanya berlaku untuk kelompok itu saja dan tidak berlaku untuk kelompok yang lain, karena distribusi skor peserta didik sudah berbeda. Untuk memahami kedua pendekatan evaluasi atau penilaian tersebut di atas, silahkan Anda membaca modul berikutnya".

Ratnawulan (2014, hlm. 269) menyatakan Terdapat beberapa ciri dari Penilaian Acuan Normatif, antara lain:

a) Penilaian Acuan Normatif digunakan untuk menentukan status setiap peserta didik terhadap kemampuan peserta didik lainnya. Dalam artian, bahwa, Penilaian Acuan Normatif digunakan apabila kita ingin mengetahui kemampuan peserta didik di dalam komunitasnya seperti di kelas, sekolah, dan lain sebagainya.

b) Penilaian Acuan Normatif menggunakan kriteria yang bersifat "relative". Maksudya, selalu berubah-ubah disesuaikan dengan kondisi dan atau kebutuhan pada waktu tersebut.

c) Nilai hasil dari Penilaian Acuan Normatif tidak mencerminkan tingkat kemampuan dan penguasaan siswa tentang materi pengajaran yang diteskan, tetapi hanya menunjuk kedudukan peserta didik (peringkatnya) dalam komunitasnya (kelompoknya).

d) Penilaian Acuan Normatif memiliki kecendrungan untuk menggunakan rentangan tingkat penguasaan seseorang terhadap kelompoknya, mulai dari yang sangat istimewa sampai dengan yang mengalami kesulitan yang serius.

Berdasarkan pengertian diatas dapat dinyatakan bahwa Penilaian Acuan Norma (PAN) yaitu suatu pendekatan penilaian yang mengacu pada rata-rata kelompok yang diperoleh dari hasil belajar siswa yang dibandingkan dengan nilai siswa lainnya yang termasuk di dalam kelompoknya.

\section{d. Macam Penilaian Hasil Belajar}

Menurut Darmadi (2011, hlm.

85) menyatakan "Instrumen adalah alat untuk mengukur informasi atau melakukan 
pengukuran. Instrumen hasil belajar adalah alat untuk melakukan pengukuran tentang kemampuan-kemampuan yang dimiliki siswa setelah ia menerima pengalaman belajarnya.

\section{1) Penilaian kognitif}

Sudjana (2010 hlm. 22) menyatakan "Ranah kognitif adalah ranah yang berkaitan dengan hasil belajar intelektual yang meliputi enam apsek yaitu: pengetahuan atau ingatan, pemahaman, aplikasi, analisis, sintesi dan evaluasi. Kedua aspek pertama disebut kognitif tingkat rendah dan ke empat aspek berikutnya termasuk kognitif tingkat tinggi". Bloom dalam Purwanto (2010, hlm. 50) "Membagi dan menyusun secara hirarkhis tingkat hasil belajar kognitif mulai dari yang paling rendah dan sederhana yaitu hafalan sampai paling tinggi dan kompleks yaitu evaluasi". Tingkatan hasil belajar kognitif menurut taksonomi Bloom dalam Arifin (2012, hlm. 89 ) antara lain: kemampuan mengingat (C1), memahami (C2), mengaplikasi (C3), kemampuan menganalisis (C4), kemampuan mengevaluasi (C5), dan mencipta (C6). Mardapi dalam Asrul (2015, hlm. 102) menyatakan "Untuk mengukur kognitif dapat dilakukan dengan tes, yaitu: tes lisan di kelas, pilihan berganda, uraian obyektif, uraian non obyektif, jawaban singkat, menjodohkan, unjuk karya dan portofolio".
Berdasarkan pendapat diatas, maka dapat dinyatakan penilaian kognitif yaitu suatu penilaian untuk mengetahui tingkat kemampuan siswa yang berkaitan dengan hasil belajar intelektual yang meliputi enam aspek yaitu pengetahuan, pemahaman, aplikasi, anlisis, sintesis dan evaluasi. Untuk mengukur penilaian kognitif dapat dilakukan dengan tes lisan maupun uraian.

\section{2) Penilaian Afektif}

Krathwohl dalam Purwanto (2010, hlm. 51) "Membagi hasil belajar afektif menjadi lima tingkatan yaitu : penerimaan, partisipasi, penilaian, organisasi dan internalisasi. Secara hirarkhis hasil belajar afektif dari tingkatan yang paling rendah dan sederhana hingga yang paling tinggi dan kompleks". Arifin (2012, hlm. 189) menyatakan "Sikap merupakan suatu kecenderungan tingkah laku untuk berbuat sesuatu dengan cara, metode, teknik dan pola tertentu terhadap dunia sekitarnya, baik berupa orang-orang maupun berupa objek-objek tertentu. Sikap mengacu kepada perbuatan atau perilaku seseorang, tetapi tidak berarti semua perbuatan identik dengan sikap". Menurut Suwandi (2010, hlm. 80) menyatakan "Sikap dalam pembelajaran dapat dinilai dari beberaa hal, yaitu sikap terhadap mata pelajaran, sikap terhadap guru atau pengajar, sikap terhadap pembelajaran, dan sikap berkaitan dengan nilai atau norma 
yang berhubungan dengan mata pelajaran".

Pada pengukuran hasil belajar afektif dinyatakan bahwa penggunaan peniliannya menggunakan skala sesuai dengan yang dikemukakan Sudjana (2013, hlm. 77) "Skala adalah alat untuk mengukur nilai, sikap, minat dan perhatian, dll. yang disususn dalam bentuk rentangan nilai sesuai dengan kriteria yang ditentukan". Sudjana (2013, hlm.77) ada dua skala untuk mengukur nilai, sikap, minat dan perhatian diantaranya yaitu:

a) Skala Penilaian

Skala penilian mengukur penampilan atau perilaku orang lain oleh esorang melalui pernyataan perilaku individu pada suatu titik continuum atau suatu kategori yang bermakna nilia. Titk atau kategori diberi nilai rentangan mulai dari yang tertinggi sampai yang terendah. Rentangan ini bisa dalam bentuk (A, B, C, D), angka $(4,3.2,1)$, atau $10,9,8,7,6,5$. Sedangkan rentangan ketegori bisa tinggi, sedang, rendah, atau baik, sedang, kurang.

b) Skala Sikap

Skala sikap digunakan untuk mengukur sikap sesorang terhadap objek tertentu. Hasilnya berupa kategori sikap, yakni mendukung (positif), menolak (negative), dan netral. Skala sikap dinyatakan dalam bentuk pernyataan untuk dinilai oleh responden, apakah pernyataan itu didukung atau ditolaknya, melalui rentangan nilai tertentu. Oleh ebab itu pernyataan yang diajukan dibagi kedalam dua kategori, yakni pernyataan positif dan pernyataan negatie. Salah satu skala sikap yang sering digunakan adalah skala Likert. Dalam skala Likert, pernyataanpernyataan yang diajukan, baik pernyataan positif atau negative, dinilai oleh subjek dengan sangat setuju, setuju, tidak punya pendapat, tidak setuju, sangat tidak setuju. Skor yang diberikan terhadap penilaian tersebut bergantung pada penilaian asal penggunaannya konsisten.

Arifin (2012, hlm. 189) menyatakan dalam mengukur sikap, Anda hendaknya memperhatikan tiga komponen sikap, yaitu :

a) kognisi, yaitu berkenaan dengan pengetahuan peserta didik tentang objek, (2) afeksi, yaitu berkenaan dengan perasaan peserta didik terhadap objek, dan (3) konasi, yaitu berkenaan dengan kecenderungan berprilaku peserta didik terhadap objek. Anda juga harus memilih salah satu model skala sikap. Adapun model-model skala sikap yang biasa digunakan untuk menilai 
sikap peserta didik terhadap suatu objek, antara lain :

b) Menggunakan bilangan untuk menunjukkan tingkattingkat dari objek sikap yang dinilai, seperti 1, 2, 3, 4 dan seterusnya.

c) Menggunakan frekuensi terjadinya atau timbulnya sikap itu, seperti : selalu, seringkali, kadang-kadang, pernah dan tidak pernah.

d) Menggunakan istilah-istilah yang bersifat kualitatif, seperti : bagus sekali, baik, sedang, dan kurang. Ada juga istilah-istilah lain, seperti : sangat setuju, setuju, ragu-ragu (tidak punya pendapat), tidak setuju, dan sangat tidak setuju.

Menurut Kochhar (2008, hlm. 56-63) menyatakan "Untuk menilai sikap atau afektif bisa menggunakan teknik non-tes". Menurut Arifin dalam Indahsari (2016, hlm. 180) Adapun perubahan sikap dan petumbuhan anak dalam psikologi hanya dapat diukur dengan teknik teknik non-tes ini bisa dilakukan dengan beberapa kegiatan diantaranya yaitu:

a) Observasi merupakan kegiatan mengamati yang dilakukan oleh guru baik langsung atau tidak langsung dengan mengacu pada pedoman observasi untuk menilai perilaku kelas baik dari segi guru maupun peserta didik yang akan didapatkan sebuah data atau informasi dari suatu fenomena kelas. b) Wawancara adalah kegiatan percakapan tanya jawab yang dilakukan oleh guru dengan peserta didik, yang dilakukan secara langsung (bertatap muka) atau tidak langsung (melalui perantara).

c) Skala sikap adalah teknik penilaian dengan memberikan pertanyaanpertanyan positif dan negatif yang akan dipilih oleh peserta didik. Jawaban atas pertanyaan-pertanyaan tersebut dibagi dalam lima skala, misalnya sangat setuju, setuju, tidak setuju, sangat tidak setuju, tidak tahu. Pertanyaan tersebut mengenai sikap peserta didik terhadap pembelajaran atau lingkungan sekolah.

d) Daftar cek merupakan suatu daftar yang digunakan oleh guru untuk mencatat dan memberi tanda tiap kejadian-kejadian yang terjadi di diri peserta didik baik kejadian kecil maupun besar dalam segala aspek, teknik seperti ini membantu guru dalam mengingat apa saja yang harus dinilai oleh guru.

e) Skala penilaian merupakan daftar cek akan dikembangan dalam bagian yang lebih luas dan terperinci yang disusun secara tingkatan yang telah ditentukan.

f) Angket yaitu alat yang digunakan untuk mengumpulkan data dan informasi yang berisi pendapat, paham dari peserta didik yang dilaksanakan secara 
tertulis yang dipengaruhi oleh pemikiran diri sendiri.

g) Studi kasus adalah kegiatan untuk memahami sebuah masalah yang dialami peserta didik dengan mencari informasi terkait dengan masalah tersebut yang natinya kemudian akan disimpulkan dan dicari penyelesaiannya, hal yang bisa dipahami dalam masalahmaslaah peserta didik misalnya dalam masalah lamban dalam memahami materi.

h) Catatan insedental yaitu cacatan yang berisi tentang kejadian singkat yang dialami atau yang telah dilakukan peserta didik dalam pembelajaran, kejadian tersebut biasanya tingkah laku peserta didik.

i) Sosiometri adalah suatu prosedur yang digunakan untuk merangkum, menyusun dan mengkualifikasikan pendapatpendapat peserta didik dalam menanggapi teman sebaya mereka bagaimana hubungan mereka dengan para temantemannya.

j) Inventori kepribadian merupakan tes kepribadian yang jawaban dari peserta didik tersebut benar semua, namun jawaban tersebut tetap akan dikualifikasikan sehingga dapat dibandingkan dengan kelompok lain.

k) Teknik pemberian penghargaan kepada peserta didik bertujuan untuk memberikan semangat, motivasi dan meningkatkan perhatian peserta didik dalam pembelajaran, serta memodifikasi tingkah laku peserta didi dari yang kurang positif menjadi lebih produktif lagi dengan adanya hadiah kepada peserta didik

Berdasarkan pendapat di atas, dapat dinyatakan bahwa ranah penilaian hasil belajar afektif adalah suatu alat untuk mengukur kemampuan yang berkenaan dengan perasaan, emosi, sikap/derajat penerimaan atau penilaian suatu obyek yang dapat diukur dengan teknik-teknik non tes.

\section{3) Penilaian Psikomotor}

Hasil belajar psikomotor tampak dalam bentuk keterampilan (skill) dan kemampuan bertindak individu. Menurut Sudjana (2010, hlm. 30) ada enam tingkatan keterampilan yaitu: (1) gerakan refleks atau gerakan yang tidak sadar, (2) keterampilan gerakkan dasar, (3) kemampuan perseptual untuk membedakan auditif dan motoris, (4) kemampuan dibidang fisik (kekuatan, keharmonisan dan ketepatan), (5) gerakkan skill mulai sederhana sampai kompleks dan (6) kemampuan yang berkenaan dengan komunikasi gerakan ekspresif dan interprestatif. Gronlund dan linn dalam Purwanto (2010, hlm. 53) mengklasifikasi hasil belajar psikomotorik menjadi enam yaitu: persepsi, kesiapan, gerakkan terbimbing, gerakan terbiasa, gerakan klomples dan 
kreativitas. Asrul (2015, hlm. 114) menyatakan Bentuk-bentuk teknik pengukuran pada ranah psikomotorik antara lain:

a) Daftar Cek

Pengukuran ranah psikomotorik dapat dilakukan dengan menggunakan daftar cek (ya tidak). Pada pengukuran ranah psikomotorik yang menggunakan daftar cek, peserta didik mendapat nilai apabila kriteria penguasaan kemampuan tertentu dapat diamati oleh penilai. Jika tidak dapat diamati, peserta didik tidak memperoleh nilai. Kelemahan cara ini adalah penilai hanya mempunyai dua pilihan mutlak, misalnya benar-salah, dapat diamati-tidak dapat diamati. Dengan demikian tidak terdapat nilai tengah.

b) Skala Rentang

Pengukuran ranah psikomotorik yang menggunakan skala rentang memungkinkan penilai memberi nilai penguasaan kompetensi tertentu karena pemberian nilai secara kontinuum di mana pilihan kategori nilai lebih dari dua. Penilaian sebaiknya dilakukan oleh lebih dari satu penilai agar faktor subjektivitas dapat diperkecil dan hasil penilaian lebih akurat. Berikut contoh skala rentang.

Menurut Arifin (2012, hlm. 149 ) mengemukakan "Tes perbuatan atau tes praktik yaitu tes yang menuntut jawaban peserta didik dalam bentuk perilaku, tindakan, atau perbuatan. Untuk melihat bagaimana peserta didik dalam menanggapi materi-materi kontroversi dan bagaimana pendapat mereka, serta bagaimana peserta didik mencari sumber lain". Sementara penilaian praktik menurut Suwandi (2010, hlm. 7286) menyatakan "Penilaian praktik merupakan penilaian yang dilakukan dengan cara mengamati kegiatan tertentu yang dilakukan oleh peserta didik. Sementara penilaian proyek merupakan penilaian terhadap suatu tugas yang diberikan oleh guru dengan kurun waktu yang telah ditentukan". Menurut Fadillah (2014, hlm. 216) menyatakan:

Penilaian keterampilan pada Kurikulum 2013 diambil dari nilai kinerja peserta didik dengan menggunakan tes praktik, proyek, dan portofolio. Tes paraktik merupakan penilaian yang menuntut respons berupa keterampilan melakukan suatu aktivitas atau perilaku berupa pembuatan suatu produk tertentu sesuai dengan tuntutan kompetensi. Oleh karena itu tes praktik dapat pula disebut tes produk. Tiga tahapan untuk menilai praktik peserta didik yaitu tahap persiapan, tahap pembuatan produk, dan tahap penilaian produk. 
Sejalan dengan pendapat fadillah yang menyatakan salah satu penilaian keterampilan yaitu menggunakan portofolio, maka menurut Sudjana (2009, hlm. 182) menyatakan:

Pengukuran ranah psikomotorik biasanya akan disatukan dengan penilaian ranah kognitif. Komponen penilaian portofolio meliputi catatan guru, hasil pekerjaan peserta didik, dan data perkembangan peserta didik. Instrumen yang dapat digunakan untuk mengukur ranah psikomotorik peserta didik dapat menggunkan matriks. Isi dari matriks menyatakan tentang perperincian aspek keterampilan yang akan diukur, ke kanan menunjukan skor yang dapat dicapai. Skor tersebut nantinya akan dijumlahkan dan dibagi jumlah variabel penilaian yang hasilnya nanti didapat dan akan dijadikan sebagai nilai psikomotorik peserta didik.

Arifin (2012, hlm. 230) menyatakan "Salah satu keunggulan penilaian portofolio adalah memberikan kesempatan kepada peserta didik untuk lebih banyak terlibat, dan peserta didik sendiri dapat dengan mudah mengontrol sejauhmana perkembangan kemampuan yang telah diperolehnya. Jadi, peserta didik akan mampu melakukan penilaian diri (self-assessment). Keterampilan menemukan kelebihan dan kekurangannya sendiri, serta kemampuan untuk menggunakan kelebihan tersebut dalam mengatasi kelemahannya merupakan modal dasar penting dalam proses pembelajaran".

Berdasarkan pendapat di atas dapat dinyatakan bahwa penilaian hasil belajar psikomtor adalah upaya untuk mengetahui kemampuan seseorang yang berkaitan dengan keterampilan (skill) yang berhubungan dengan aktivitas fisik. Penilaian tersebut dapat dilakukan saat proses berlangsung yang dilakukan dengan cara mengamati kegiatan tertentu yang dilakukan oleh peserta didik.

\section{Metode Penelitian}

Metode penelitian yang digunakan dalam penelitian ini adalah Penelitian Tindaka Kelas (ClassroomAction Research). Penelitian ini yaitu suatu penelitian yang dilakukan guru di dalam kelas melalui kegiatan pembelajaran dengan menggunakan model pembelajaran discovery learning.

Menurut Arikunto (dalam, Taniredja 2013, hlm. 15) mengartikan "Penelitian tindakan kelas merupakan suatu pencermatan terhadap kegiatan belajar berupa sebuah tindakan, yang sengaja dimunculkan dan terjadi dalam sebuah kelas secara bersama. Tindakan tersebut diberikan oleh guru atau dengan arahan dari guru yang dilakukan 
oleh siswa”. Aqib (2007, hlm. 12) menyatakan :

Dalam bahasa Inggris PTK diartikan dengan Clasroom Action Rasearch, disingkat CAR. Namanya sendiri sebetulnya sudah menunjukan isi yang yang terkandung didalmnya. Oleh karena itu ada tiga kata yang membentuk pengertian tersebut , maka ada tiga pengertian pula yang dapat diterangkan.

a) Penelitian adalah kegiatan mencermati suatu obyek menggunakan aturan metodologi tertentu untuk memperoleh data atau informasi yang bermanfaat untuk meningkatkan mutu dari suatu hal yang menarik minat dan dianggap penting bagi peneliti.

b) Tindakan adalah sesuatu gerak kegiatan yang sengaja dilakukan dengan tujuan tertentu, yang dalam penelitian PTK berbentuk rangkaian siklus kegiatan.

c) Kelas adalah sekelompok siswa yang dalam waktu yang sama menerima pelajaran yang sama dari seorang guru. Kelas bukan wujud ruangan tetapi sekelompok peserta didik yang sedang belajar.

Sejalan dengan pendapat diatas, Iskandar (2012, hlm.21) mengemukakan:

Pengertian (PTK)

Penelitian

Tindakan Kelas
adalah
suatu
kegiatan penelitian
ilmiah yang
dilakukan secara
rasional, sistematis
dan empiris reflektif
terhadap berbagai
tindakan yang
dilakukan oleh guru
atau dosen (tenaga
pendidik),
kolaborasi (tim
peneliti) yang
sekaligus sebagai
peneliti, sejak
disusunnya suatu
perencanaan
sampai penilaian
terhaadap tindakan
nyata di dalam
kelas yang berupa
kegiatanbelajar
mengajar, untuk
memperbaiki dan
meningkatkan
kondisi
pembelajaran yang
dilakukan.

Berdasarkan pendapat di atas dapat dinyatakan bahwa penelitian tindakan kelas adalah suatu penelitian dalam kegiatan pembalajaran pada kondisi, keadaan dan situasi yang ada di dalam kelas yang dilaksanakan untuk memcahkan permasalaahanpermasalaahan yang terjadi untuk meningkatkan pembelajaran di kelas.

Model penelitian tindakan kelas yang digunakan dalam 
penelitian ini adalah model penelitian yang dikembangkan oleh Stephen Kemmis dan Robbin Mc Taggart. Aqib (2007, hlm. 22) menyatakan Berdasarkan jenis penelitian sebagaimana dipaparkan sebelumnya, rancangan atau desain PTK yang digunakan adalah menggunakan model PTK Kemmis \& Mc. Taggart yang dalam alur penelitiannya yakni meliputi langkah - langkah: 1) Perencanaan (planning), 2) Aksi/ tindakan (acting), 3) Observasi (observing),

And, 3) Refleksi (refleting).

\section{Subjek Penelitian}

Subjek dalam penelitian ini adalah siswa kelas IV SDN Cikitu 03 dalam pembelajaran Subtema kebersamaan dalam keberagaman dengan siswa kelas IV berjumlah 30 orang yang terdiri atas 15 siswa perempuan dan 15 siswa laki-laki. Siswa kelas IV SDN Cikitu 03 dipilih sebagai subjek penelitian karena selain hasil belajar siswa pada subtema kebersamaan dalam keberagaman tema kebersamaan dalam keberagaman, dan di kelas IV ini juga dinilai perlu adanya suatu pembaharuan variasi model pembelajaran agar hasil belajar siswa bisa meningkat . Pelaksanaan penelitian ini pada semester ganjil tahun pelajaran 2018-2019.

\section{Objek Penelitian}

a. Tempat Penelitian

Penelitian ini dilaksanakan dikelas IV SDN Cikitu 03 jln. Cikitu
Desa Cikitu Kecamatan Pacet Kab. Bandung.

b. Waktu penelitian

Penelitian ini dilaksanakan pada semester I tahun pelajaran 2018-2019 selama 3 bulan sejak bulan juni 2018. Alasan memilih subjek penelitian ini, karena ingin meningkatkan hasil belajar siswa dengan mengacu pada aspek kognitif. Pada proses pembelajaran yang terjadi terlihat guru masih mengajar dengan metode ceramah dan pembelajaran hanya berpusat pada guru jadi pada kegiatan pembelajaran guru menjadi satu satunya sumber ilmu (teacher center) sehingga siswa kurang aktif karena tidak diberikan kesempatan untuk terlibat dalam kegiatan pembelajaran. Sasarannya adalah penggunaan model Discovery Learning untuk meningkatkan hasil belajar siswa pada subtema Kebersamaan dalam Keberagaman.

\section{Hasil Penelitian dan Pembahasan}

1. Rencana Pelaksanaan Pembelajaran (RPP) Subtema Kebersamaan dalam Keberagaman Berdasarkan hasil observasi yang telah dilakukan oleh observer terhadap peneliti mengalami peningkatan pada setiap siklusnya. Pada siklus I tindakan I mendapat nilai 2,53 memiliki krieteria cukup baik dengan persentase $63 \%$ dan tindakan 2 mendapat nilai 2,8 
memiliki kriteria cukup baik dengan persentase $70 \%$. Siklus II pada tindakan I mendapat nilai 2,93 memiliki kriteria baik dengan persentase $72,25 \%$ dan tindakan 2 mendapat nilai 3,0 memiliki kriteria baik dengan persentase $75 \%$. Siklus III pada tindakan I mendapat nilai 3,33 memiliki kriteria sangat baik dengan persentase $83 \%$ dan tindakan 2 mendapat nilai 3,46 memiliki kriteria sangat baik dengan persentase $87 \%$. Perencanaan pembelajaran yang dibuat oleh peneliti pada dasarnya sudah sesuai dengan materi pembelajaran yang akan disampaikan kepada siswa karena pada pembelajaran sebuah perencanaan sangatlah penting dalam melakukan sebuah pembelajaran pendidikan agama Islam, maka perencanaan wajib dilakukan seorang guru. Sesuai pendapat Majid (2008, hlm. 63) menyatakan "Perencanaan dapat diartikan sebagai proses penyusunan materi pelajaran, penggunaan media pengajaran, penggunaan pendekatan dan metode pengajaran, serta penilaian dalam suatu alokasi waktu yang akan dilaksanakan pada masa tertentu untuk mencapai tujuan yang telah ditentukan".

Mulyasa (2007, hlm. 183) mengungkapkan "RPP adalah rencana penggambaran prosedur dan manajemen pengajaran untuk mencapai satu atau lebih kompetensi dasar yang ditetapkan dalam standar kompetensi dan di jabarkan dalam silabus. Sedangakan dalam pembuatan RPP juga sesuai dengan kurikulum yang diterapkan disekolah yaitu kurikulum 2013, sehingga pelaksanaan sebelum pembelajaran dalam penggunaan model pembelajaran, media pembelajaran dan juga evaluasi sudah mempunyai perencanaan yang matang yang tertulis dalam RPP diperlukan agar guru dapat menarik perhatian dan memotivasi siswa agar dapat mengikuti pembelajaran dengan baik. Oleh karena itu adanya Rencana Pelaksanaan Pembelajaran (RPP) dalam setiap siklus yang disusun secara sistematis kemudian untuk mencapai tujuan pembelajaran dalam RPP setiap siklusnya disusun berdasarkan langkahlangkah pembelajaran dengan menggunakan Model Discovery Learning ( DL ).

\section{Kegiatan Belajar Mengajar (KBM) Pada Subtema Kebersamaan Dalam Keberagaman}

Penilaian KBM oleh observer terhadap peneliti mengalami peningkatan pada setiap siklusnya. Pada siklus I tindakan ke I memperoleh nilai 2,56 memiliki kriteria cukup baik dengan persentase $64 \%$ dan tindakan 2 memperoleh nilai 2,88 memiliki kriteria baik dengan persentase $72 \%$. Pada siklus II tindakan 1 
memperoleh nilai 3.0 memiliki kriteria baik dengan persentase $75 \%$ dan pada tindakan 2 memperoleh nilai 3,2 memiliki kriteria sangat baik dengan persentase $80 \%$. Pada siklus III tindakan 1 memperoleh nilai 3,36 memiliki kriteria sangat baik dengan persentase $84 \%$ dan pada tindakan 2 memperoleh nilai 3,60 memiliki kriteria sangat baik dengan persentase $90 \%$. Dari data tersebut dapat disimpulkan bahwa semua proses pembelajaran berjalan terlaksana dengan baik, setelah ditempuh melalui 3 siklus dengan 6 pembelajaran.

Menurut Oemar Hamalik (239: 2006) pembelajaran adalah "suatu kombinasi yang tersusun meliputi unsur-unsur manusiawi, material fasilitas, perlengkapan dan prosedur yang saling mempengaruhi tercapainya tujuan pembelajaran". Pelaksanaan Pembelajaran dalam setiap siklus yang dilaksanakan untuk mencapai tujuan pembelajaran berdasarkan langkah-langkah pembelajaran dengan menggunakan Model Discovery Learning ( DL ). Sedangkan tujuan model pembelajaran discovery learning menurut Azhar dalam Aini (2016 hlm. 99) adalah:

a) Kemampuan berfikir agar lebih tanggap, cermat dan melatih daya nalar (kritis, analisis dan logis)

b) Membina dan mengembangkan sikap ingin lebih tahu c) Mengembangkan aspek kognitif, afektif dan psikomotorik,

d) Mengembangkan sikap, keterampilan kepercayaan murid dalam memutuskan sesuatu secara tepat dan objektif.

Berdasarkan hasil analisis diatas maka pada penelitian ini pelaksanaan pembelajaran mengacu pada tujuan odel discovery leraning dan langkahlangkah pelaksanaan model discovery learning sehingga hasil pelaksanaan pembelajaran dapat terlaksana dengan sangat baik.

\section{Perilaku Guru Dalam Model Discovery Learning}

Dari ketiga siklus tersebut dapat dilihat jika sudah ada beberapa siswa yang sangat aktif akan tetapi diharapkan model ini dapat berpengaruh positif pada pembelajaran laju reaksi sehingga siswa yang kurang aktif maupun belum aktif dapat menjadi lebih aktif dalam pembelajaran sesuai dengan pendapat Hosnan (2014, hlm. 282) menyatakan "Pembelajaran discovery learning adalah suatu model untuk mengembangkan cara belajar siswa aktif dengan menemukan sendiri, menyelidiki sendiri, maka hasil yang diperoleh akan setia dan tahan lama dalam ingatan, tidak akan mudah dilupakan. Dalam kegiatan belajar dengan menggunakan model discovery learning, siswa benar-benar melakukan kegiatan belajar dengan aktif dalam menemukan 
sendiri, menyelidiki sendiri maka hasil yang diperoleh akan mudah diingat maka hasil belajar akan mengalami peningkatan karena dengan menggunakan model ini siswa melaksanakan praktek secara langsung tentang faktor yang mempengaruhi laju reaksi, tidak hanya sekedar menghafal teori sehingga siswa memperoleh pengalaman langsung dan nyata yang akan dapat diingat untuk jangka panjang sedangkan guru hanya sebagai pembimbing dalam proses pembelajaran sesuai dengan pendapat Sardiman (2012, hlm. 145) "Dalam mengaplikasikan model pembelajaran Discovery Learning guru berperan sebagai pembimbing dengan memberikan kesempatan kepada siswa untuk belajar secara aktif, sebagaimana pendapat guru harus dapat membimbing dan mengarahkan kegiatan belajar siswa sesuai dengan tujuan". Pelaksanaan pembelajaran model discovery learning mengacu pada langkahlangkah pembelajaran model discovery learning, yang dikemukakan oleh Syah dalam (Hosnan, 2004, hlm. 289) ada beberapa prosedur yang harus dilaksanakan dalam kegiatan belajar mengajar secara umum yaitu:

a. Stimulation

(stimulasi/pemberian rangsangan)

Pertama-tama pada tahap ini siswa dihadapkan pada sesuatu yang menimbulkan tanda Tanya, kemusian dilanjutkan untuk tidak memberi generalisasi, agar timbul keinginan untuk menyelidiki sendiri. Disamping itu guru dapat memulai kegiatan KBM dengan mengajukan pertanyaan, anjuran membaca buku, dan aktivitas belajar lainnya yang mengarah pada persiapan memecahkan masalah. Stimulasi pada tahap ini berfungsi untuk menyediskan kondisi interaksi belajar yang dapat mengembangkan dan membantu peserta didik dalam mengeksplorasi bahan.

b. Problem stattment

(Pernyataan/Identifikasi masalah)

Setelah dilakukan stimulasi langkah selanjutnya adalah guru memberikan kesempatan kepada siswa untuk mengidentifikasi sebanyak mungkin agenda-agenda masalah yang relevan dengan bahan pelajaran, kemudian salah satunya dipilih dan dirumuskan dalam bentuk hipotesis (jawaban sementara atas pertanyaan masalah.

c. Data collection

(Pengumpulan Data)

Ketika eksplorasi berlangsung guru juga memberi kesempatan kepada para siswa untuk mengumpulkan informasi sebanyak-banyaknya yang relevan untuk membuktikan benar atau tidaknya hipotesis. 
Pada tahap ini berfungsi untuk menjawab pertanyaan atau membuktikan benar tidaknya hipotesis. Dengan demikian siswa diberi kesempatan untuk mengumpulkan (collection) berbagai informasi yang relevan membaca literatur, mengamati objek wawancara dengan narasumber, melakukan uji coba sendiri dan sebagainya.

\section{d. Data Processing}

(pengolahan Data)

Pengolahan data merupakan kegiatann mengolah data dan informasi yang telah diperolah para peserta didik baik melalui wawancara, observasi, dan sebagainya. Semua informasi hasil bacaan, wawancara, observasi dan sebagainya, semua diolah, diacak, diklasifikasikan, ditabulasi, bahkan bila perlu dihitung dengan cara tertentu serta ditafsirkan pada tingkat kepercayaan tertentu.

e. Verification

Pembuktian)

Pada tahap ini siswa melakukan pemeriksaan secara cermat untuk membuktikan benar atau tidaknya hipotesis yang ditetapkan tadi dengan temuan alternative, dihubungkan dengan hasil data processing.

f. Generalization

(Menarik

kesimpulan/Generalis asi)
Tahap generalisasi /menarik kesimpulan adalah proses menarik sebuah kesimpulan yang dapat dijadikan prinsip umum dan berlaku untuk semua kejadian atau masalah yang sama dengan memperhatikan hasil verifikasi.

Sehubungan dengan langkah model discovery learning di atas, maka pembelajaran discovery learning yaitu dimana siswa bisa belajar secara aktif, mandiri dan mampu menyelidiki serta mencari penemuan-penemuan baru dari informasi yang mereka temukan. Hal tersebut sejalan dengan pendapat Ruseffendi (2006, hlm. 329) "Model (mengajar) penemuan adalah metode mengajar yang mengatur pengajaran sedemikian rupa sehingga anak memperoleh pengetahuan yang sebelumnya belum diketahuinya itu tidak melalui pemberitahuan, sebagian atau seluruhnya ditemukan sendiri". Pembelajaran discovery learning siswa lebih aktif dan memahami materi pelajaran. Siswa juga lebih berani untuk bertanya kepada guru, hal ini didukung denga suasana pembelajaran yang menyenangkan, dibandingkan dengan model konvensional, siswa kurang aktif dan siswa terlihat kurang antusias dalam mengikuti pembelajaran. Sesuai dengan hasil penelitian yang di lakukan oleh ( Pratiwi 2014) dengan Judul "Penggunaan Model Discovery Learning Dengan Pendekatan 
Saintifik Untuk Meningkatkan Hasil Belajar Siswa Kelas V dii MI Walisongo Kebonrowopucang Karangdadap Pekalongan Tahun 2014/2015". Bahwa penilaian observasi keterlaksanaan model discovery learning oleh guru dibuat berdasarkan sintaks dari model discovery learning dan diamati oleh satu orang observer selama tiga kali pertemuan. pada pertemuan pertama total skor yang diperoleh $=$ 14, dengan skor maksimal adalah 28. Melalui perhitungannya maka diperolehlah persentase pelaksanaannya sebesar $50 \%$ dengan kategori cukup baik. Perhitungan yang sama juga berlaku untuk pertemuan kedua dan ketiga yang memperoleh skor berturut-turut, yaitu 18 dan 22 . Perhitungan persentase $64,2 \%$ dengan kategori baik, dan untuk pertemuan ketiga memperoleh persentase $78,57 \%$ dengan kategori baik. hal tersebut menunjukan bahwa keterlaksanaan model discovery learning oleh guru berdasarkan sintaks sangat baik diterapkan dalam pembelajaran.

Berdasarkan hasil Penilaian pelaksanaan sintak discovery learning oleh observer pada peneliti ini mengalami peningkatan pada setiap siklusnya maka pada penelitian ini dapat dikatakan pelaksanaan sintak discovery learning pada penelitian ini berhasil dilaksanakan dengan sangat baik.

\section{Respon Siswa Terhadap Tingkahlaku Guru Pada}

Subtema Kebersamaan dalam Keberagaman

Dari diagram tersebut respon siswa terhadap tingkahlaku guru setelah pembelajaran mengalami peningkatan sebagai akibat dari perlakuan yaitu pembelajaran dengan menggunakan model discovery learning. Respon siswa terhadap guru bisa meliputi berbagai bentuk seperti perhatian, proses internal terhadap informasi, tindakan nyata dalam bentuk partisipai kegiatan belajar seperti memecahkan masalah, mengerjakan tugas-tugas yang diberikan oleh guru, dan lain-lain.

Pada kegiatan belajar siswa diberi stimulus oleh guru agar siswa dapat memberikan tanggapan atau repon yang bisa ditunjukan setelah pembelajaran dengan menggunakan angket. Pada proses belajar mengajar banyak kegiatan belajar siswa yang dapat ditempuh melalui respon seperti yang diungkapkan Surya Subrata (2006, hlm. 287) menyatakan "Respon ialah reaksi objektif dari individu terhadap stimulus yang berasal dari lingkungannya dengan menggunakan alat yang disebut efektor". Menurut Kartono (1996, hlm. 58) menyatakan "Respon merupakan gambaran ingatan dari pengamatan". Sedangkan menurut Ahmadi ( 1999, hlm. 166) mendefinisikan "Respon merupakan bentuk kesiapan dalam menentukan sikap baik dalam bentuk positif atau negatife 
terhadap objek atau situasi". Definisi ini menunjukan adanya pembagian respon sebagai berikut:

a. Respon positif

Sebuah bentuk respon, tindakan atau sikap yang menunjukan atau memperlihatkan, menrima, mengakui, menyetujui, serta melaksanakan norma-norma yang berlaku dalam individu itu berada.

b. Respon Negatif

Bentuk respon, indakan atau sikap yang menunjukan atau memperlihatkan penolakan atau tidak menyetujui terhadap norma-norma yang berlaku dimana individu itu berada.

Sejalan dengan teori tersebut, dalam pembelajaran yang telah dilaksanakan oleh peneliti, siswa tidak selalu memberikan respon positif terhadap tingkah laku guru dalam pembelajaran yang telah dilaksanakan, adaula yang memberikan respon negative, namun dengan dilakukan perbaikan dalam setiap siklusnya respon siswa terus mengalami peningkatan pada setiap siklusnya, sehingga secara keseluruhan siswa memberikan krespon positif terhadap tingkah laku guru. Hal ini sejalan pula dengan hasil penelitian oleh Afrinaldi yang berjudul "Penerapan model pembelajaran discovery learning terhadap hasil belajar siswa kelas $\mathrm{V}$ SDN Surabaya". Pada penelitian tersebut respon siswa terhadap pembelajaran discovery learning mengalami peningkatan dengan hasil angket respon siswa pada siklus I mendapatkan hasil respon $77,39 \%$ dengan kategori baik, siklus II mendapatkan hasil $80 \%$ dengan kategori baik dan pada siklus III mendapatkan nilai 93,25\% dengan kategori sangat baik. Maka pada penelitain tersebut respon siswa terhadap guru dengan menggunakan model discovery learning dikategorikan sangat baik dan dikatkan penelitian tersebut berhasil. Hal ini diperkuat dengan pendapat Kurniasih dan Sani (2004, hlm. 66) menyatakan "salah satu kelebihan model discovery learning yaitu meninmbulkan rasa senang pada siswa, karena tumbuhnya rasa menyelidiki dan berhasil". Hal ini memperjelas bahwa respon siswa terhadap guru setelah menggunakan model discovery learning sangat baik.

\section{Hasil Belajar Siswa Subtema Kebersamaaan Dalam Keberagaman}

Berdasarkan hasil penelitian pada siklus I dari 30 orang siswa, yang mencapai KKM 11 orang dengan persentase $37 \%$ dengan nilai terendah 20 dan hasil tertinggi 80. Hasil observasi yang telah dilakukan oleh observer menunjukan bahwa sebagian besar siswa belum dapat mencapai KKM sehingga perlu dilakukan tindakan selanjutnya dalam upaya memperbaiki dan menyempurnakan kekurangan. Pada siklus II hasil belajar siswa 
yang mencapai KKM sebanyak 17 orang dari 30 orang siswa dengan persentase $57 \%$ dengan nilai terendah 30 dan nilai tertinggi 90 . Hasil observasi yang telah dilakukan oleh observer menunjukan bahwa siswa sudah mulai memahami materi yang disampaikan, dan proses pembelajaran sudah mulai dapat dipahami dengan baik. Pada siklus III yang mencapai KKM sebanyak 27orang dengan persentase 90\% dengan nilai terendah 40 dan tertinggi 90. Sehingga dapat disimpulkan bahwa hasil belajar siswa sudah mencapai target yang diharapkan yaitu nilai rata-rata lebih dari 70.

Berdasarkan hasil belajar siswa pada penelitian ini, adanya Peningkatan hasil belajar siswa merupakan hasil dari proses belajar. Hal tersebut seperti yang dikemukakan oleh Hamalik (2008, hlm. 155) menyatakan "Hasil belajar adalah sebagai terjadinya perubahan tingkah laku pada diri seseorang yang dapat diamati dan diukur dalam bentuk pengetahuan, sikap dan keterampilan. Perubahan tersebut dapat di artikan sebagai terjadinya peningkatan dan pengembangan yang lebih baik sebelumnya yang tidak tahu menjadi tahu". Dalam kegiatan belajar, perubahan-perubahan itu senantiasa bertambah dan tertuju untuk memperoleh suatu yang lebih baik dari sebelumnya. Jadi, jika siswa benar-benar melakukan kegiatan belajar maka akan timbul perubahan tingkah laku pada dirinya yang bersifat sadar, aktif, positif, kontinue, dan bertujuan atau terarah. Salah satu perubahan tingkah laku dapat diamati dari meningkatnya hasil belajar siswa. Sejalan dengan pendapat Nana Sudjana (2009, hlm. 3) menyatakan "Hasil belajar siswa pada hakikatnya adalah perubahan tingkah laku sebagai hasil belajar dalam pengertian yang luas mencangkup bidang kognituf, afektif dan psikomotorik". Hal ini sejalan dengan hasil penelitian Ismaul husnah yang berjudul "Peningkatan Hasil Belajar Melalui Model Pembelajaran Discovery Learning Pada Tema 2 Kelas IV SDN Beringin Raya" Pada Siklus I terlihat dari 24 orang siswa, terdapat 14 orang siswa belum tuntas $(58,33 \%)$ dan yang tuntas mencapai 10 orang siswa (41,67\%). Pada siklus II terdapat 7 orang yang belum tuntas $(29,16 \%)$ dan yang tuntas mencapai 17 orang siswa $(70,83 \%)$ sedangkan siklus III terdapat 2 orang yang belum tuntas $(8,33 \%)$ dan yang tuntas mencapai 17 orang siswa $(91,66 \%)$ artinya terdapat suatu peningkatan hasil pembelajaran dengan menggunakan model discovery learning pada tema 2 dapat meningkatkan hasil belajar siswa. Berdasarkan beberapa hasil penelitian yang sudah dilakukan di atas terbukti bahwa metode pembelajaran discovery learning 
dapat meningkatkan hasil belajar siswa. Hal ini memperjelas bahwa model discovery leraning dapat meningkatkan hasil belajar siswa karena pembelajaran dengan menggunakan model discovery learning dilakukan dengan lebih menekankan kepada keaktifan dan kerja sama siswa dalam diskusi kelompok serta partisipasi aktif dari siswa. Sehingga siswa dapat memperoleh pengetahuan dan pemahaman yang lebih serta menjadikan siswa lebih aktif dan kritis terhadap permasalahanpermasalahan yang sedang terjadi. Maka hasil tes preetes dan posttest dengan menggunakan model discovery learning selalu mengalami peningkatan pada setiap siklusnya. Dengan demikian penggunaan model discovery learning pada subtema kebersamaan dalam keberagaman berhasil meningkatkan hasil belajar siswa.

\section{Kesimpulan}

Penelitian tindakan kelas ini dilaksanakan di kelas IV SDN Cikitu 03 beralamat di Jalan Cikitu Kecamatan Pacet Kabupaten Bandung. Penelitian ini bertujuan untuk meningkatkan hasil belajar siswa pada subtema kebersamaan dalam kebragaman dengan menggunakan model discovery learning. Mengacu pada hasil penelitian yang telah dilakukan dalam tiga siklus, dapat ditarik kesimpulan sebagai berikut:
1. Perencanaan pembelajaran pada siklus I memperoleh hasil sebesar $70 \%$. Pada siklus II perencanaan pembelajaran yang peneliti susun meningkat dengan perolehan hasil sebesar $75 \%$, pada siklus III perencanaan pembelajaran memperoleh hasil $86 \%$. Dari penjelasan diatas, dapat disimpulkan bahwa perencanaan pelaksanaan pembelajaran pada siklus III sudah cukup maksimal dan mencapai target peneliti. Dengan demikian RPP yang telah dibuat dinyatakan berhasil.

2. Pelaksanaan pembelajaran pada siklus I dirasa masih belum maksimal dalam melakukan pembelajaran dengan menggunakan model discovery learning, hal ini dapat dilihat dari kinerja guru sehingga hasil belajar siswa yang diperoleh belum mencapai target yang diinginkan. Dari analisis diperoleh data bahwa pelaksanaan pembelajaran pada siklus I memperoleh hasil persentase sebesar $72 \%$. Pada siklus II pelaksanaan pembelajaran yang peneliti lakukan memperoleh hasil persentase $80 \%$. Pada siklus III pelaksanaan pembelajaran memperoleh hasil persentase sebesar $90 \%$. Hasil meningkat pada siklus III dan dikatakan berhasil sehingga tidak perlu 
diadakan penelitian lagi. Dari keterangan data di atas mengenai pelaksanaan pembelajaran dapat disimpulkan bahwa pelaksanaan pembelajaran dengan menggunakan model discovery learning pada siklus III sudah cukup maksimal dan mencapai target peneliti. Dengan demikian pelaksanaan pembelajaran yang telah dilaksanakan dinyatakan berhasil.

3. Berdasarkan hasil observasi sintak discovery learning atau perilaku guru dalam menggunakan langkah-langkah pembelajaran dengan menggunakan sintak model discovery learning pada siklus I dirasa guru belum maksimal dalam melakukan langkahlangkah tersebut. Dapat dilihat dari hasil peniliaan pada siklus I memperoleh hasil persentase $66 \%$ dengan kategori cukup baik. Pada siklus II memperoleh hasil persentase $76 \%$ dengan kriteria baik. Pada siklus III memperoleh hasil persentase sebesar $86 \%$ dengan kriteria sangat baik. Hasil tingkah laku guru dengan menerapkan sintak discovery learning meningkat pada siklus III dan dikatakan berhasil.

4. Berdasarkan hasil analisis angket respon siswa terhadap tingkah laku guru setelah pembelajaran, menunjukan bahwa respon siswa terhadap guru pada siklus I mendapatkan hasil respon $77,39 \%$ dengan kategori baik, siklus II mendapatkan hasil 80\% dengan kategori baik dan pada siklus III mendapatkan nilai $93,25 \%$ dengan kategori sangat baik. Maka pada penelitain ini respon siswa terhadap guru dengan menggunakan model discovery learning dikategorikan sangat baik.

5. Berdasarkan hasil analisis belajar siswa, menunjukan bahwa pada siklus I hasil evaluasi dengan siswa yang telah tuntas mencapai KKM sebanyak 11 orang siswa dari jumlah siswa 30 orang dengan persentase $37 \%$. Sedangkan siswa yang belum tuntas mencapai KKM sebanyak 19 orang dengan persentase $63 \%$. Pada siklus II mengalami peningkatan dengan hasil evaluasi siswa yang telah tuntas mencapai KKM sebanyak 17 orang siswa dari jumlah 30 orang siswa dengan persentase $57 \%$. Sedangkan siswa yang belum tuntas mencapai KKM yaitu 13 orang siswa dari jumlah siswa 30 orang dengan persentase $43 \%$. Pada siklus III mengalami peningkatan yang sangat baik yaitu siswa yang telah tuntas mencapai KKM yaitu sebanyak 27 orang siswa dari jumlah 30 orang siswa dengan persentase $90 \%$. 
Sedangkan yang belum tuntas mencapai KKM yaitu sebnyak 3 orang siswa dari jumlah siswa 30 orang dengan persentase $10 \%$. Hasil pada siklus III ini meningkat dan sudah sesuai dengan harapan peneliti dan dapat dikatakan berhasil sehingga tidak perlu di adakan penelitian lagi. Dengan demikian dilihat dari hasil posttest yang dilakukan pada setiap siklus pembelajaran pada subtema kbersamaan dalam kebragaman dengan menggunakan model discovery learning dapat meningkatkan hasil belajar siswa.

Berdasarkan penjelasan di atas secara keseluruhan dapat disimpulkan bahwa penggunaan rencana pelaksanaan pembelajaran, pelaksanaan pembelajaran dan tingkahlaku guru dengan menggunakan model discovery learning dapat meningkatkan hasil belajar siswa pada subtema kebersamaan dalam keberagaman di kelas IV SDN Cikitu 03.

\section{DAFTAR PUSTAKA}

A .M. Sadirman (2012). Interaksi dan motivasi belajar mengajar. Jakarta: PT Raja Grafindo Persada.

Agung, Iskandar (2012). Panduan Penelitian Tindakan Kelas Bagi Guru. Jakarta:Bestari Buana Murni.
Aqib, Zainal. (2007). Penelitian Tindakan Kelas untuk Guru. Bandung: Yrama Widya.

Arifin, Zainal (2012). Evaluasi Pembelajaran. Bandung: PT. Remaja Rosdakarya Offset.

Arikunto, Suharsimi (2002). Prosedur Penelitian Suatu Pendekatan

Praktek.Jakarta: PT. Rineka Cipta.

Asrul, Rusdy Ananda dan Rosnita (2014). Evaluasi Pembelajaran. Bandung: Ciptapustaka Media.

Azhar, Arsyad (2015). Media Pembelajaran. Jalarta: Rajagrafido Persada.

Azhari (2015). Penerapan model pembelajaran discovery learning terhadap peningkatan hasil belajar siswa kelas XI-IPA1 pada materi sistem pernapasan di SMA Negeri Unggul Sigli, 7(1). diakses dari laman web tanggal 9 juni 2018 dari: http https://www.ejurnal.com/2017/04/penerap an-model-pembelajarandiscovery_15.html

Budiningsih, Asri (2005). Belajar dan Pembelajaran. Jakarta: Rineka Cipta

Dahar, Ratna Willis (1996). Teoriteori Belajar. Jakarta; Erlangga.

Darmadi, Hamid (2011). Metode Penelitian Pendidikan. Bandung: Alfabeta. 
Fadillah, M. (2014). Implementasi Kurikulum 2013 Dalam Pembelajaran SD/MI, SD/MTS, dan SMA/MA. Yogyakarta : Ar-Ruzz Hamalik, Oemar (2008). Kurikulum dan Pembelajaran . Jakarta: Sinar Grafika.

Belajar Mengajar. Jakarta:
Bumi Aksara.
(2009), Proses Belajar Mengajar. Jakarta : PT bumi Aksara

Hanafiah, Nanang dan Cucu Suhanah (2009). Konsep Strategi Pembelajaran Bandung: Rafika Aditama Hosnan (2014). Pendekatan Saintifik dan Kontekstual dalam Pembelajaran Abad 21. Ghalia Indonesia: Bogor. Iskandar, Dadang dan Narsim (2015). Penelitian Tindakan Kelas dan Publikasinya Untuk Kenaikan Pangkat dan Golongan Guru \& Pedoman Penulisan PTK bagi Mahasiswa. Cilacap: Ihya Media

Notoadmodjo, Soekidjo (2010). Metode Penelitian Kesehatan. Jakarta: PT.Rineka Cipta.

Purwanto (2013). Evaluasi Hasil Belajar. Yogyakarta: Pustaka Pelajar.

Belajar. Surakarta:Pustaka Belajar.

_. (2010). Evaluasi Hasil Belajar. Yogyakarta : Pustaka Pelajar.

Ratnawulan, Elis dan Rusdiana (2014). Evaluasi Pembelajaran. Bandung: Pustaka Setia.

Sanjanya, Wina (2006). Strategi pembelajaran berorientasi standar proses pendidikan. Jakarta: Prenanda Media Group

Sardiman, A.M. (2012). Interaksi dan Motivasi Belajar Mengajar. Jakarta:Rajawali Press.

Slameto (2010). Belajar dan Faktorfaktor yang Mempengaruhi. Rineka Cipta: Jakarta.

Sudjana, Nana (2013). Penilaian hasil proses belajar mengajar. Bandung: PT Remaja Rosdakarya, Bandung.

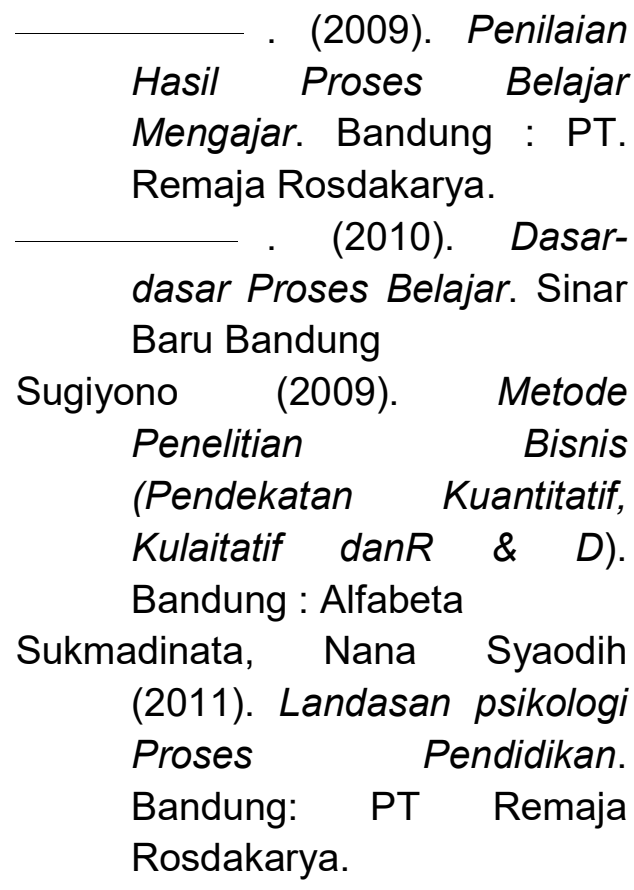


Surya, Mohamad (2014). Psikologi Guru Konsep dan Aplikasi. Bandung: Alfabeta.

Suryosubroto (2009). Proses Belajar Mengajar di Sekolah. Jakarta: PT Rineka Cipta.

Suwandi Joko, Drs. (2010). Penelitian Tindakan Kelas Classroom Action Research. Surakarta : Qinant.

Syaodih, Nana (2011). Landasan psikologi Proses Pendidikan. Bandung: PT Remaja Rosdakarya

Taniredja, Tukiran dkk. (2013). Penelitian Tindakan Kelas untuk pengembangan profesi guru praktik, praktis, dan mudah.

Bandung:Alfabeta

Trianto (2010). Moodel Pembelajran Terpadu. Jakarta: Bumi Aksara.

(2012). Moodel
Pembelajran $\quad$ Terpadu.
Jakarta: Bumi Aksara.

Trisnamansyah, Sutaryat (2015). Evaluasi Pembelajaran. Bandung: CV Pustaka Setia Widodo, A. (2005). Taksonomi Tujuan Pembelajaran. Didaktis. 4(2), 61-69. Diakses dari laman web tanggal 19 April 2018 dari: http://file.upi.edu/Direktori/F PMIPA/JUR._PEND._BIOL OGI/196705271992031-

ARI_WIDODO/2005-

Revisi_Taksonomi_BloomDidaktis.pdf
A. Majid (2008). Perencanaan Pembelajaran Mengembangkan Standar Kompetensi. Bandung : PT. Remaja Rosda Karya.

Nurbayani, Etty (2012). Penilaian Acuan Patokan (PAP) Di Perguruan Tinggi (Prinsip Dan Operasionalnya). Diakses dari laman web tanggal 28 juli 2018 dari: https://www.researchgate.n et/publication/307849668_P enilaian_Acuan_Patokan_P AP_di_Perguruan_Tinggi_P rinsip_dan_Operasionalnya.

Permendikbud no 53 (2015). Penilaian Hasil Belajar. diakses dari laman web tanggal 5 Mei 2018 dari: https://luk.staff.ugm.ac.id/at ur/bsnp/Permendikbud5320 15Penilaian\%20HasilBelajar Dikdasmen.pdf

Aini, Mahlihatul (2016). Pengaruh penggunaan model pembelajaran discovery learning (DL) terhadap hasil belajar tematik siswa Kelas V SD NEGERI 2 Labuhan Ratu Bandar Lampung Tahun pelajaran 2014/2015. Skripsi FKIP UNIVERSITAS LAMPUNG: Tidak diterbitkan.

Widyastuti, Sri (2015). PENERAPAN MODEL PEMBELAJARAN DISCOVERY LEARNING PADA MATERI KONSEP ILMU EKONOMI. Skripsi 
Didaktik : Jurnal Pendidikan Guru Sekolah Dasar, ISSN : 24775673 Sekolah Tinggi Keguruan dan IImu Pendidikan Subang Volume IV Nomor 2, Desember 2018

\begin{tabular}{|c|c|}
\hline FKIP UNIVRSITAS NEGRI & UNIVERSITAS \\
\hline $\begin{array}{l}\text { SURABAYA: } \\
\text { diterbitkan. }\end{array}$ & $\begin{array}{l}\text { PASUNDAN: } \\
\text { diterbitkan. }\end{array}$ \\
\hline Ramdani, Sidiq (2017). Penerapan & https://dosenpsikologi.com/kognitif- \\
\hline Model Pembelajran & afektif-dan-psikomotorik \\
\hline $\begin{array}{l}\text { Discovery Learning untuk } \\
\text { meningkatkan sikap percaya }\end{array}$ & $\begin{array}{l}\text { diakses tanggal } 16 \text { Mei } \\
2018 .\end{array}$ \\
\hline diri dan hasil belajar siswa & https://luk.staff.ugm.ac.id/atur/bsnp \\
\hline kelas IV SDN Buah Batu & /Permendikbud532015Penil \\
\hline $\begin{array}{l}\text { Baru pada tema Makananku } \\
\text { sehat dan bergizi . Skripsi }\end{array}$ & $\begin{array}{l}\text { aian\%20HasilBelajarDikdas } \\
\text { men }\end{array}$ \\
\hline
\end{tabular}

